
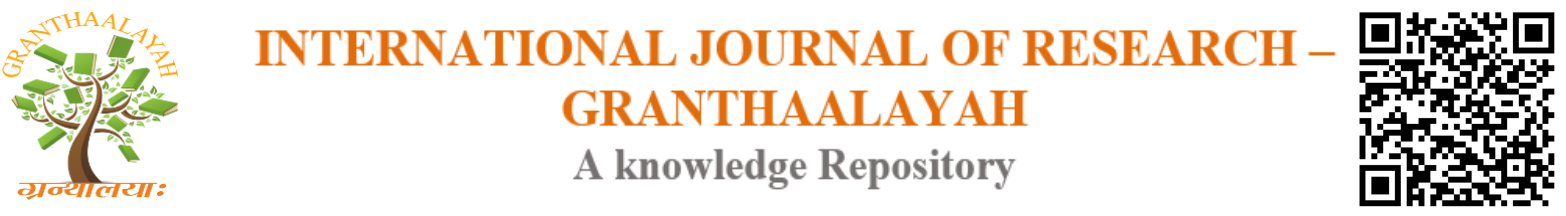

Science

\title{
AWARENESS AND USE OF DIGITAL RESOURCES AND SERVICES IN THE IIT DELHI LIBRARY
}

\author{
Dr. Javed Khan ${ }^{* 1}$ \\ ${ }^{* 1}$ Assistant Professor, Swami Vivekanand Subharti University, Meerut, INDIA
}

DOI: https://doi.org/10.29121/granthaalayah.v4.i6.2016.2639

\section{ABSTRACT}

Information technology (IT) has thrown a new challenge to the libraries. The technology has shown a great impact on the services of the libraries. Libraries use IT for better services and satisfying diverse user needs. Libraries have transformed into digital and virtual libraries where books, journals, and magazines have changed into e-books, e-journals, and e-zines. This has increased the global dissemination of information. Electronic resources (e-resources) are easily accessible in the remote areas. The e-resources solve storage problems and control the flood of information. Print sources are being digitized. There is a great need to study the use of e-resources and investigate the factors that are a hindrance to their use. The present study is an attempt to examine the usage of electronic resources at IIT Delhi. The study confirmed that respondents were aware of the e-resources and various types of e-resources, $e$ database, and e-journals. The study recommended the improvement in the access facilities with high internet speed and subscription to more e-resources.

Keywords:

E-resources, database, e-journal, e-books, virtual library.

Cite This Article: Dr. Javed Khan, "AWARENESS AND USE OF DIGITAL RESOURCES AND SERVICES IN THE IIT DELHI LIBRARY" International Journal of Research Granthaalayah, Vol. 4, No. 6 (2016): 64-71.

\section{INTRODUCTION}

The electronic resources are systems in which information is stored electronically and made accessible through electronic systems and computer networks. These resources include OPAC, CD-ROMs, Online- Databases, E-journals E-books, Internet resources etc. Multiple accesses speed, richer in content, reuse, timeliness, anywhere access is some of the features of eresources. IEEE Explore, Elsevier Science Direct, ASCE Journals, ASME Journals, EBSCO, Springer, etc. are the example of some famous e-resources available in India and overseas. These resources are paid resources and only accessible after payment. These resources are only limited access. These are available in so many different packages in different price ranges. In India, these resources are available through INDEST-AICTE consortium and UGC-INFONET 
consortium on some discounted prices. Electronic resources provide access to information that might be restricted to the user because of geographical location or finances. Electronic resources also provide access to current information as these are often updated frequently. Through their various search techniques electronic resources provide extensive links to explore additional resources or related content. In addition, electronic resources are considered as important resources of teaching, research and training. Thus, most of libraries as well as the universities of the present day provide electronic resources for higher education and research.

Digital Resources constitute an important part of a library collection being the most important vehicle for global scholarly communication. Tremendous developments in ICT in the recent years have given amazing boost to electronic publishing. As a result the information which is being generated at intense pace from all the directions worldwide for all the themes is now being published in form of digital resources. With advancement of technology the libraries are moving towards digital resources, which are found to be less expensive and more helpful for easy access of information. In the digital era the commonly available digital resources like CD-ROMs, Online Databases, Library OPACs and Internet etc., which are replacing the print media. In recent years, digital resources are in common use in scholarly communication and we can interpret this situation in various ways. One of main functions of the college is the creation and dissemination of new knowledge by education and research.

\section{LITERATURE REVIEW}

To review the literature, search was conducted with combination of various key terms such as 'eresources', 'e-journals' and 'e-journals consortia' in Library and Information Science Abstracts (LISA), Emerald database, EBSCO database, Science Direct and other databases, including search on the e-journals websites and search engines. In addition searches, bibliographies journals were also reviewed for more sources, as well as website of UGC-Info net digital library consortium and many eminent experts were consulted in the field of e-journals.

Biradar, et al. reported the results of a study exploring university students' and teachers' use of search engines for retrieval of scholarly information. The main objectives were to examine the use of search engines, use of popular search engines, factors influencing for search engines' use, use of search strategy for information retrieval and also to know the methods of learning search strategy by students and faculty in the university environment. Results of the study showed that 100 per cent of the students and 97.91 per cent of the faculty used search engines for retrieval of information on the internet. Google and Yahoo received the highest overall ratings. The study revealed that majority of the respondents took help from their friends and used help messages of search engines to learn the search strategy.

Dadzie investigated the use of e-resources by students and faculty of Asheshi University, Ghana, to determine the level of use, the type of information accessed and the effectiveness of the library's communication tools for information research and problems faced in using e-resources. Results indicate that 85 per cent of respondents used the internet to access information, and that respondents mainly accessed information in the library by browsing books on the shelves. 
Fortin explored faculty members' use and their information seeking behaviours and activities on the internet at Angelo State University. Using both quantitative and qualitative methodologies, differences were found between tenured and tenure-track faculty members on the perceived value of the internet to meet their research and classroom information needs. Similar differences were also found among faculty members in the broad discipline areas of the humanities, social sciences, and sciences. Tenure-track faculty members reported a higher average internet use per week than tenured faculty members.

Adika analysed internet use among faculty members of universities in Ghana. Research results showed that in spite of the benefits of the internet, its use among faculty was still very low. The main reasons for this were the lack of access to the internet and the need for training. It was suggested that university authorities must take immediate steps to provide general access points to faculty through computer laboratories. Here, librarians, information professionals, and computer scientists have vital roles to play in organising training and refresher sessions for faculty in getting up-to-date information via Internet for teaching and research.

Al-Ansari conducted a study on internet use by the faculty members of Kuwait University. This study was designed to investigate the patterns of internet use by faculty including purposes of use, its impact on teaching and research, internet resources used, and the problems faced while using the internet. A structured questionnaire was used to collect data from the faculty of four colleges of Kuwait University, i.e., arts, social sciences, sciences, and engineering. The study revealed that the internet was mostly used for communication, research, and publication for saving time, to find up-to-date information, and to cooperate with their colleagues. Slow speed, lack of time, and lack of access from home were some of the major problems.

Majid \& Abazova explored the use of e-resources relevant to computer literacy among academic staff of the International Islamic University, Malaysia. Nearly all respondents considered themselves to have good or very good computer skills.

Madusudhan focused on the use of e-resources by research scholars of Kurukshetra University. The main aim was to determine the use of e-resources, users' skills in handling e-resources, and the purposes of their use. Further, the paper aimed to highlight the problems faced by research scholars in accessing e-resources, their opinions on features of e-resources and their views on usefulness of e-resources compared to those of conventional sources. The findings showed that e-resources have become an integral part of the information needs of research scholars at Kurukshetra University. Further, it was found that e-resources could be good substitutes for conventional resources, if the access becomes fast and more computer terminals could be installed to provide fast access to e-resources. Google was the most widely used search engine for locating information electronically.

\section{The basic objectives of the present study are to:}

1) To find out the awareness and uses of E- Resources by users.

2) To know how the students are using the different types of digital resources.

3) To find out the problems faced by the respondents while using resources.

4) To know the purpose and utilization of the digital resources services by the users. 
5) To determine the level of satisfaction of users about Digital resources and services.

\section{METHODOLOGY}

The study was conducted using a questionnaire method. The study comprised under graduate, post graduate and research scholars of the various departments of IIT Delhi. Altogether there were around 180 under graduate, post graduate and research scholars in various departments. Out of this, a sample of 150 under graduate, post graduate and research scholars were taken at random as they study unit.

\section{DATA ANALYSIS \& INTERPRETATION}

Satisfied with the electronic information services

\begin{tabular}{|l|l|l|l|}
\hline $\begin{array}{l}\text { Satisfaction about E- } \\
\text { information services }\end{array}$ & U.G N=60 & P.G N=60 & Research Scholars N= 30 \\
\hline Dissatisfied & $4(6.66 \%)$ & - & - \\
\hline Satisfied & $44(73.33 \%)$ & $48(80 \%)$ & $28(93.33 \%)$ \\
\hline $\begin{array}{l}\text { Somewhat } \\
\text { satisfied }\end{array}$ & $12(20 \%)$ & $12(20 \%)$ & $2(6.66 \%)$ \\
\hline Never & - & - & - \\
\hline
\end{tabular}

This table Reveals that the satisfaction level with E-information services: 4(6.66 present) U.G users "Dissatisfied" with E-information services where 44(73.33present) U.G users, 48(80present) P.G users and 28(93.33present) research scholars "Satisfied" with E-information services. 12(20present) U.G users, 12(20present) P.G users and 2(6.66present) Research scholars are "Somewhat Satisfied" with E-information services. For "Never" users give no response.

\section{Use the library e-media}

\begin{tabular}{|l|l|l|l|}
\hline Library E-Media & U.G N=60 & P.G N=60 & Research Scholars N=30 \\
\hline Accessing the library catalogue & $18(30 \%)$ & $16(26.66 \%)$ & $18(60 \%)$ \\
\hline Accessing E-mail & $16(26.66 \%)$ & $46(60 \%)$ & $8(26.66 \%)$ \\
\hline Online databases & $26(43.33 \%)$ & $48(80 \%)$ & $28(93.33 \%)$ \\
\hline Internet searching & $44(73.33 \%)$ & $36(60 \%)$ & $27(90 \%)$ \\
\hline General web browsing & $35(58.33 \%)$ & $12(20 \%)$ & $13(43.33 \%)$ \\
\hline
\end{tabular}

(Multiple answer were permitted)

This table shows the users opinion why they use E-media: 18(30present) U.G users, 16(26.66present) P.G users and 18(60present) Research Scholars use library E-media for "Accessing the library catalogue". 16(26.66present) U.G users, 46(60present) P.G users and 8(26.66present) Research Scholars use library E-media for "Accessing E-mail". 26(43.33present) U.G users, 48(80present) P.G users and 28(93.33present) Research Scholars use library E-media for "Online database". 44(73.33present) U.G users, 36(60present) P.G users and 27(90present) 
Research scholars use library E-media for "Internet searching". 35(58.33present) U.G users, 12(20present) P.G users and 13(43.33present) Research scholars use library E-media for "General web Browsing".

Which type of Electronic media do you prefer to use

\begin{tabular}{|l|l|l|l|}
\hline Electronic media & U.G N=60 & P.G N=60 & Research Scholars N=30 \\
\hline CD-ROM & $56(93.33 \%)$ & $52(86.66 \%)$ & $27(90 \%)$ \\
\hline Microfilms/Microfiche & - & $20(33.33 \%)$ & $9(30 \%)$ \\
\hline Magnetic Tape & $8(13.33 \%)$ & $8(13.33 \%)$ & $10(33.33 \%)$ \\
\hline Audio Tape & $36(60 \%)$ & $36(60 \%)$ & $18(60 \%)$ \\
\hline Video Tape & $36(60 \%)$ & $52(86.66 \%)$ & $24(80 \%)$ \\
\hline
\end{tabular}

(Multiple answer were permitted)

This table shows the preferred E-media to use: 56(93.33present) U.G users, 52(86.66present) P.G Users and 27(90present) Research scholars of GBU library prefer CD-ROMs. No response of U.G users, 20(33.33present) PG Users and 9(30present) Research Scholars prefer to use Microfilms/Microfiche. Whereas 8(13.33present) U.G users, 8(13.33) P.G Users and 10(33.33present) Research Scholars prefer Magnetic Tape. On the other hand 36(60present) U.G, P.G users and 18(60present) Research Scholars preferred Audio Tape. And 36(60present) U.G users, 52(86.66present) P.G user and 24(80present) Research scholars prefer Video Tapes.

Purpose of using online services

\begin{tabular}{|l|l|l|l|}
\hline Purpose & U.G N=60 & P.G N=60 & Research Scholars N=30 \\
\hline $\begin{array}{l}\text { To check for general } \\
\text { information }\end{array}$ & $28(46.66 \%)$ & $24(40 \%)$ & $26(86.66 \%)$ \\
\hline $\begin{array}{l}\text { Just to browse } \\
\begin{array}{l}\text { To search for information for } \\
\text { assignment }\end{array}\end{array}$ & $15(25 \%)$ & $20(33.33 \%)$ & $13(43.33 \%)$ \\
\hline For news and current affairs & $18(30 \%)$ & $36(60 \%)$ & $3(10 \%)$ \\
\hline
\end{tabular}

(Multiple answer were permitted)

This table shows the purpose of using online services: 28(46.66present) U.G users, 24(40present) P.G users and 26(86.66present) Research Scholar's purpose using online services is "To check for general information". 15(25present) U.G users, 20(33.33present) P.G users and 13(43.33present) Research Scholar's purpose using online services is "Just to browse". 43(71.66present) U.G users, 48(80present) P.G Users and 3(10present) Research Scholar's purpose using online services is "To search for information for assignment". 18(30present) U.G users, 36(60present) P.G users and 16(53.33present) Research Scholar's purpose using online services are "For news and current affairs. 
Problems faced while using resources

\begin{tabular}{|l|l|l|l|}
\hline Purpose & U.G N=60 & P.G N=60 & Research Scholars N=30 \\
\hline Slow access speed & $28(46.66 \%)$ & $12(20 \%)$ & $13(43.33 \%)$ \\
\hline $\begin{array}{l}\text { Difficulty in finding relevant } \\
\text { information }\end{array}$ & $16(26.66 \%)$ & $15(25 \%)$ & $3(10 \%)$ \\
\hline $\begin{array}{l}\text { It takes too long to view/ } \\
\text { download pages }\end{array}$ & $12(20 \%)$ & $12(20 \%)$ & $2(6.66 \%)$ \\
\hline $\begin{array}{l}\text { Too much information } \\
\text { retrieved }\end{array}$ & $8(13.33 \%)$ & $4(6.66 \%)$ & $8(26.66 \%)$ \\
\hline $\begin{array}{l}\text { Difficulty in using digital } \\
\text { resources due to lack of IT } \\
\text { knowledge }\end{array}$ & $18(30 \%)$ & $16(26.66 \%)$ & $9(30 \%)$ \\
\hline Limited access to computers & $36(60 \%)$ & $15(25 \%)$ & $26(86.66 \%)$ \\
\hline
\end{tabular}

(Multiple answer were permitted)

The table shows that while faced problem 28 (46.66present) UG and 12(20 present) PG and Research Scholar 13 (43.33 present) to slow access speed. And 16 (26.66 present) UG and PG 12(20 present) and Research Scholar 3(10 present) are facing problems to relevant information. And the 12(20 present) UG and PG or 2(6.66 present) Research Scholar are facing problems to download pages. And other hand 8(13 present) UG and PG 4(6.66 present) Research Scholar 8 (26.66 present) too much information retrieved. UG 18(30 present) PG 16(26.66 present) and Research Scholar 9(30 present) are facing problems using digital resources due to lack of IT knowledge. UG 36(60 present) and PG 15(25 present) and Research Scholar 26(86.66) to limited access to computers.

\section{CONCLUSION}

The e-resources are the best means of getting current and up-to-date information. The library environment has currently undergone drastic changes in terms of collections and services. The proliferation of e-resources has had a significant impact on the way the academic community uses, stores, and preserves information. The advantages of e-resources have drawn attention of the library users to a great extent. Accordingly, these resources have occupied a significant place in the collection and budget of almost all libraries. Research scholars' attitude seems to be very positive towards e-resources for their study and research and the role of libraries as gateways to provide assistance in accessing these resources. The study shows that e-resources have radical impact on the changing higher education environment. It is interesting that e-resources usage among under graduate, postgraduate students, research scholars at IIT Delhi Library. This study has highlighted that research scholar respondents tare at first position in their overall methods of searching e-resources, PG student respondents at the second position, undergraduates respondents the last position. The use of electronic information sources for study and research purposes must be encouraged and proper training should be organised from time to time. This is the first comprehensive study of the use of e-resources by the users. It is hoped that its findings 
would help the University and its libraries in framing its policies and programmes related to eresources to facilitate teaching and research.

\section{FINDINGS}

1) Users are satisfied with the electronic information services.

2) Mostly users are using online databases.

3) Mostly users prefer use Electronic media CD-ROM.

4) Most of the PG and UG users are using for information for assignment and RS are for general information.

5) Mostly UG and RS are Facing Problems while using resources for Limited access to computers and PG due to lack of IT knowledge.

\section{RECOMMENDATION}

Based on the findings of the study, the following recommendations are made for the effective use of e-resources by the users of IIT Delhi.

- The LIS professionals of the Central Library have to spread more awareness on eresources. In this context the website of library and newsletter of the Institution should highlight the available e-resources in the library regularly.

- Higher speeds Wi-Fi campus needs to be developed by Central Library, so that users can use online e-resources and internet within the campus according to their convenience.

- Besides e-journals and e-database, e-books and other e-resources (both online and offline) should be acquired by the Central Library.

- The speed of internet needs to be increased for quick access to the available e-resources.

- Qualified IT experts should be made available to solve the problems of networking and hardware.

- The Central Library needs to arrange various users' orientation and training programmes for the optimum use of available e- resources, and also subscribe database. Also, product trials of various e-resources for specific user groups need to be introduced.

- Basic training in hardware and software such as MS Office, internet searching, and use of e-resources should be included in the curriculum of each department.

\section{REFERENCES}

[1] Biradar, B.S. (2008) Use of search engines for retrieval of scholarly information: A case study. IASLIC Bulletin, 53(4), 215-22.

[2] Dadzie, P.S. (2005) Electronic resources: Access and usage at Asheshi University College. Comp. Wide Inf. Sys, 22(5), 290-97.

[3] Fortin, Maurice G. (2000) Faculty use of the World Wide Web: Modeling information seeking behavior in a digital environment. University of North Texas, Denton, Texas.

[4] Gifty, Adika. (2003) Internet use among faculty members of universities in Ghana. Library Review, 52(1), 29-37.

[5] Husain, Al-Ansari (2006) Internet use by the faculty members of Kuwait University. Electronic Library, 24(6), 791-803. 
[6] Majid, S. \& Abazova, A.F (1999) Computer literacy and use of electronic information sources by academics: A case study of International Islamic University of Malaysia. Asian Libraries, 8(4), 100-111.

[7] Madhusudhan, Margam (2010) Use of electronic resources by research scholars of Kurukshetra University. Electronic Library, 28(1), 492-506. 